\title{
Distribution and microhabitat selection of Hydropsyche exocellata Dufour (Trichoptera, Hydropsychidae) in a Mediterranean river affected of organic pollution: the Guadaira River (S. Spain)
}

\author{
Alfonso Gallardo-Mayenco ${ }^{1, *}$ and Antonio Ruíz ${ }^{2}$ \\ 1 Departamento de Biología Vegetal \& Ecología, Universidad de Sevilla, Aptdo. 1095, 41080 Sevilla, Spain. \\ 2 Puerto de las Palomas 11, 11406 Jeréz de la Frontera (Cádiz), Spain. argjerez@ hotmail.com. \\ *Corresponding author: algama@correo.cop.es.
}

\begin{abstract}
Distribution and microhabitat selection of Hydropsyche exocellata Dufour (Trichoptera, Hydropsychidae) in a Mediterranean river affected of organic pollution: the Guadaira River (S. Spain)

During the wet season, floods in the Guadaira river can reach up to $2000 \mathrm{~m}^{3} / \mathrm{s}$ flow, whereas during dry season the river only receives crude domestic sewage effluents and periodical industrial effluents from olive oil factories. In this study, the distribution of Hydropsyche exocellata along the watercourse of the Guadaira river during the flood and drought periods and its preferences for the available microhabitats were studied. H. exocellata was the only hydropsychid found along the river, except at one site at the headwater where it was found coexisting with $\mathrm{H}$. infernalis Schmid Its higher abundances were found at the start of the dry period (June) and at its end (October). From the IBMWP values obtained at the sampling sites, we found that the highest densities of $H$. exocellata were coincidental with ranks of this index characterizing moderately polluted waters, whereas it was not found at sites where pollution reached highest levels. Thus, it seems it avoids sites extremely polluted in the study area. From the stepwise multiple regression analysis and microhabitat selection results, we can infer that to get a successful population size it requires an environment basically consisting of fast water current velocity and firm substrate (stones).
\end{abstract}

Key words: Hydropsychidae, Mediterranean rivers, organic pollution, longitudinal and seasonal distributions, microhabitats.

\section{RESUMEN}

Distribución y selección de microhábitat de Hydropsyche exocellata Dufour (Trichoptera, Hydropsychidae) en un río mediterráneo afectado por contaminación orgánica: El río Guadaira (S. España)

Durante la estación húmeda, las inundaciones en el río Guadaira pueden alcanzar hasta los $2000 \mathrm{~m}^{3} / \mathrm{s}$ de caudal, mientras que durante el estiaje solo recibe aguas residuales procedentes de los núcleos urbanos y, puntualmente, los procedentes de las industrias de maceración de la aceituna. En este trabajo se estudia la distribución $\mathrm{H}$. exocellata a lo largo del curso principal del rio Guadaira durante los periodos de estiaje e inundación y sus preferencias por los microhábitats disponibles. H. exocellata fue el único hydropsíquido encontrado a lo largo del río, excepto en una estación de cabecera donde se encontró coexistiendo con $\mathrm{H}$. infernalis Schmid. Las abundancias más altas se encontraron a comienzos (Junio) y a finales (Octubre) del estiaje. A partir de los valores del indice IBMWP obtenidos en los sitios de muestreo, se encontró que las densidades más altas de H. exocellata coincidian con rangos de este índice que caracterizan aguas moderadamente contaminadas, mientras que no se encontró en las estaciones donde la contaminación era mayor, es decir, en el área de estudio parece evitar los sitios extremadamente contaminados. A partir de los resultados del análisis de regresión múltiple y de selección de microhábitats, podemos inferir que para lograr un tamaño de población exitoso, H. exocellata requiere un ambiente consistente básicamente en aguas de velocidad rápida y sustrato firme (piedras).

Palabras clave: Hydropsychidae, ríos mediterráneos, contaminación orgánica, distribución longitudinal y estacional, microhabitats. 


\section{INTRODUCTION}

The genus Hydropsyche is represented in the Iberian Peninsula by 21 proven species (González, 2003), covering a wide range of ecological requirements (Higler \& Tolkamp, 1983; De Soto et al., 1994; Fernández-Aláez et al., 2002). Differences were found in previous studies between the distribution of several Hydropysche species in relation with some water physical-chemical para- meters in some basins of the south Iberian Peninsula (Gallardo-Mayenco et al., 1998; RuízGarcía, 2000). Moreover, Hydropsyche exocellata was the most abundant hydropsychid species, and, of the whole of macroinvertebrate species, one of the most tolerant to the high levels of natural salinity measured in the study area (Gallardo-Mayenco, 1994; Gallardo-Mayenco et $a l .$, 1998). This agreed with the results of Piscart et al. (2005), who found, in a French river, that

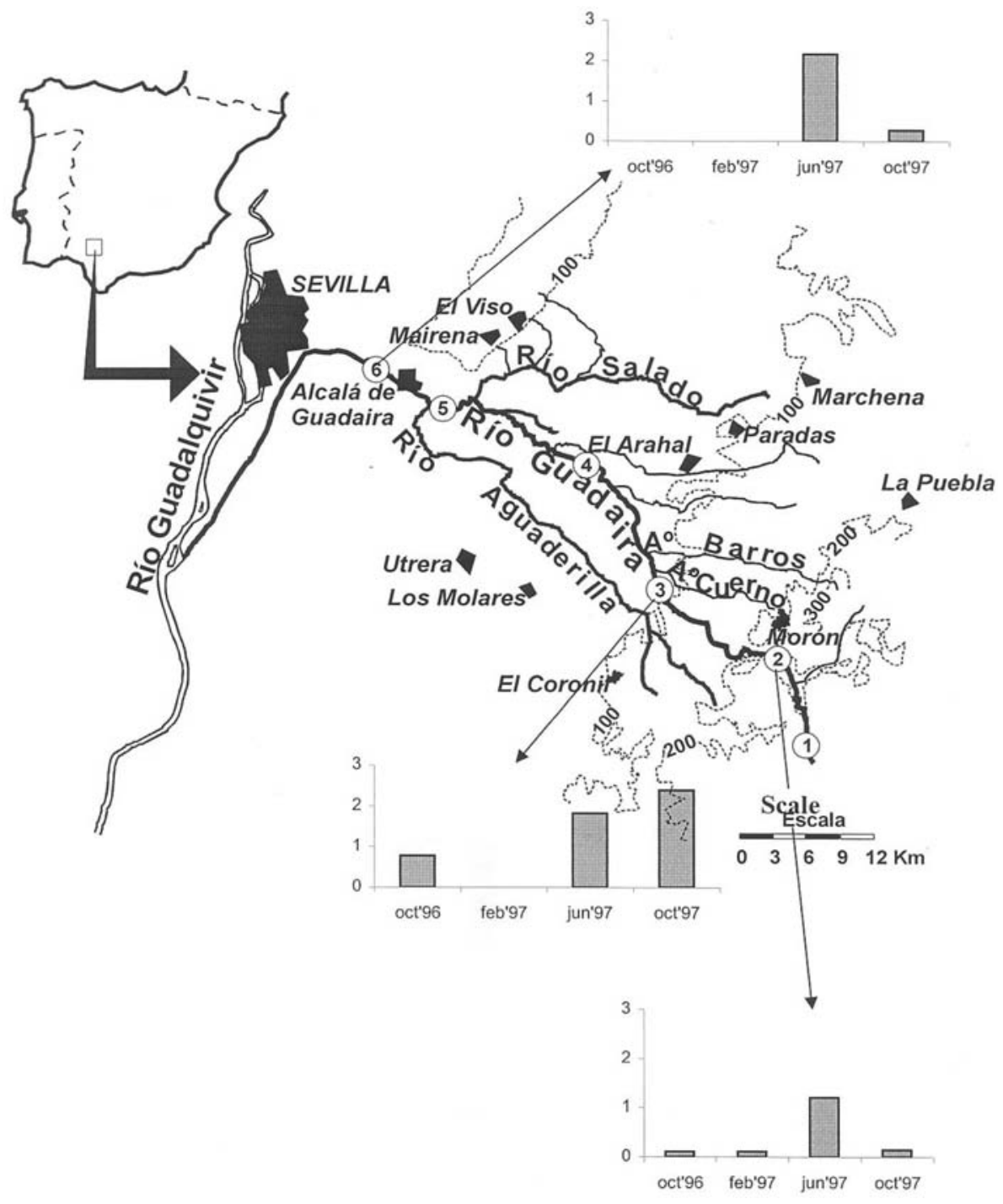

Figure 1. Study area and sites sampled in the Guadaira river. Graphics show the relative abundances (at logarithmic scale) of H. exocellata at each sampling site and date. Área de estudio y sitios muestreados en el río Guadaira. Las gráficas muestran las abundancias relativas (a escala logarítmica) de H. exocellata en cada sitio de muestreo y fecha. 
H. exocellata increased its abundance following increases in water salinity. According to Bonada et al. (2005), this is an indicative species of calcareous/sedimentary lowland rivers, and some authors emphasized about its tolerance to organic pollution in rivers of the Iberian Peninsula (González et al., 1985; Bargos et al., 1990; Basaguren, 1990; De Soto et al., 1994), occupying the last position in the ranking of sensitivity to pollution in a study on caddisfly species from Spanish Mediterranean basins (Bonada et al., 2004a).

With regard to the habitat preferences, hydropsychid larvae are rheophilic net-spinning inhabitants of stream riffles where they filter suspended particulate matter (McElhone et al., 1987; Czachorowski, 1989). At the microhabitat level, preferences of Hydropsychidae larvae towards one type of substrate have been shown by several authors (Czachorowski, 1989; Fairchild \& Holomuzki, 2002). Hildrew \& Edington (1979) found a highly significant relation between microhabitat and larvae instar for $\mathrm{Hy}$ dropsyche siltalai. In addition, Osborne \& Herricks (1987) found that Hydropsyche species mature larvae could inhabit places where water current velocity is faster than where the youngest larvae inhabit. We have not found information about the microhabitat preferences of Hydropsyche larvae in the Iberian Peninsula.

The objectives of this study were: a) to study the distribution of $H$. exocellata along the watercourse of the Guadaira river according to the longitudinal gradient of organic pollution during the flood and drought periods, and b) to study its preferences for available microhabitats.

\section{STUDY AREA}

Samples were taken at six sites along the main watercourse of the Guadaira River (Fig. 1), and they were part of the work to assess the water quality of the river using macroinvertebrate communities (Gallardo-Mayenco et al., 2004). The Guadaira River is characterized by a headwater with a very gentle relief, at an altitude of 330 m.a.s.l. at the highest site sampled, and a natural salinity due to the evaporites present at the headwater. During the wet season, floods reach up to $2000 \mathrm{~m}^{3} / \mathrm{s}$ of discharge, whereas during dry season the river only receives crude domestic sewage effluents. Periodically, the river receives industrial effluents from olive oil factories. The watershed is under intensive agricultural use and shows quite high population levels, resulting in high pollution levels (Prenda \& Gallardo-Mayenco, 1996).

In the upper stretch of the river, the channel is very narrow ( $1 \mathrm{~m}$ wide during flood at site G1) reaching 40 and $35 \mathrm{~m}$ wide downstream (at sites G5 and G6 respectively). Width decreases to $0.5 \mathrm{~m}$ (G1), $18 \mathrm{~m}$ (G5), and $10 \mathrm{~m}$ (G6) during droughts. The bank vegetation is composed of Scirpus sp., Juncus sp., Typha domingensis, and Tamarix africana. Additionally, we found Nasturtium officinalis (G1), Ranunculus sp., and Phragmites communis (G2), Lemna gibba (G6), and dense masses of filamentous algae covering the stones of the riffle at sites G2, G3, G5 and G6.

In a previous study, from which data for $H$. exocellata was extracted for this work (GallardoMayenco et al., 2004), the distribution of the physical and chemical variables in the space determined by the components I and II of the Principal Component Analysis showed for the axis I an altitude-organic pollution gradient with the variables related to organic load against altitude, conductivity, and suspended solids. The axis II showed a nitrogen oxidation-reduction gradient, with nitrate against ammonia.

\section{METHODS}

Samples were taken during the drought (October 25, 1996), after flood (February 8, 1997), start of drought (June 17, 1997), and drought (October 4, 1997) periods. Before the sampling of Feb'97, rainfall was higher than the average calculated for the 1960-1990 period (GallardoMayenco et al., 2004). Macroinvertebrate samples (from where samples of $H$. exocellata were extracted) were taken using a triangular $35 \mathrm{~cm}$ long net by the kick-net method. Each site was sampled at each period taking in consideration the different microhabitats found, as 
Table 1. Criteria used to separate the microhabitats found at each sampling site and date. Criterios usados para separar los microhábitats encontrados en cada sitio de muestreo y fecha.

\begin{tabular}{|c|c|c|c|}
\hline $\begin{array}{l}\text { Principal Habitat Descriptors: } \\
\text { Water current velocity }^{(1)}\end{array}$ & Predominant substrate & Vegetation $^{(2)}$ & Organic sediments $^{(3)}$ \\
\hline \multicolumn{4}{|l|}{ Classes: } \\
\hline 1 still $0-5 \mathrm{~cm} / \mathrm{s}$ & 1 sands & 1 presence & 1 presence \\
\hline 2 slow $<25 \mathrm{~cm} / \mathrm{s}$ & 2 stones & 2 absence & 2 absence \\
\hline 3 medium $25-50 \mathrm{~cm} / \mathrm{s}$ & 3 slime & 3 litter & \\
\hline 4 fast $>50 \mathrm{~cm} / \mathrm{s}$ & 4 gravels & & \\
\hline
\end{tabular}

described afterwards. For each microhabitat 2-5 replicate samples were taken. The abundances are expressed semi quantitatively (relative abundances) as individuals per unit of effort (Elliot, 1977), being one unit of effort, one net sample during $30 \mathrm{~s}$ of effective time. To assess the water quality we used the IBMWP index (Alba-Tercedor et al., 2002). A complete description of the sampling procedure can be found in Gallardo-Mayenco et al. (2004).

We made a stepwise multiple variable regression analysis to establish the relationship between the relative abundance of $H$. exocellata (dependent variable) and the physico-chemical variables (alkalinity, suspended solids, chemical oxygen demand, phosphate, nitrate, nitrite, ammonia, conductivity, water current velocity, and width) and IBMWP index (independent variables). A complete description of analytical techniques and physico-chemical features can be found in Gallardo-Mayenco et al. (2004).

To discriminate the microhabitat preferences of $H$. exocellata, samples were taken separating the different microhabitats found at each site and date. To distinguish each microhabitat we used four principal parameters (which we designated as principal habitat descriptors): water current velocity, predominant substrate, vegetation, and organic sediments. Moreover, each one of these principal habitat descriptors was separated in several classes according to the following criteria: water current velocity, according to the velocity ranks following Dolédec et al. (1999); substrate, depending on which was the predominant constituent (sands, stones, slime, or gravels); vegeta- tion, if it was fresh (presence), decomposing (litter) or if the microhabitat was bare (absence); presence or absence of organic sediments was considered to indicate microhabitats in anaerobic conditions (Table 1).

To know in which phase of growth the populations of $H$. exocellata were at each site and date, we measured the width of larval head (Edington \& Hildrew, 1981) and assigned each individual to the respective instar larvae according to Soler \& Puig (1999). Specimens found in pupal stage were also counted.

To search for significant differences in the abundances of $H$. exocellata, we used chisquared goodness-of-fit test. For the application of the stepwise multiple variable regression analysis, all values were $\log (x+1)$ transformed.

\section{RESULTS}

\section{Hydropsyche exocellata spatial and seasonal distribution}

We found $H$. exocellata at sites G2, G3, and G6. At the end of the sampling, we collected a total of 950 larvae, 31 pupae and 1 male adult (absolute abundances). At site G2, it was found coexisting with Hydropsyche infernalis Schmid (in June of 1997).

Taking into consideration the relative abundances of $H$. exocellata at each site and date (considering the whole sample, i. e., adding the abundances found in the microhabitats belonging to the site and date), the higher abundances were 

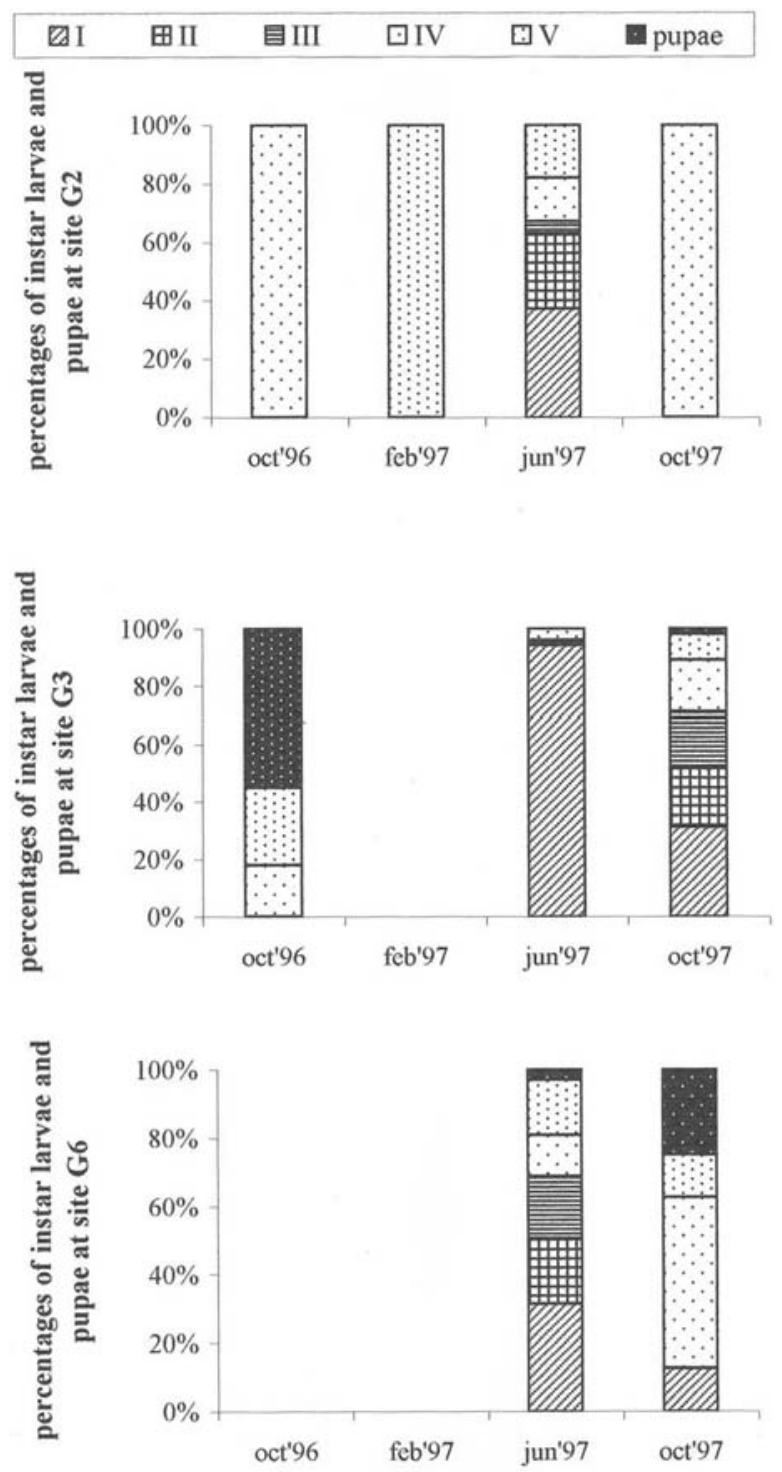

Figure 2. Percentages of abundance of larval instars and pupae in which the populations of $H$. exocellata were found at each sampling site and date. Porcentajes de abundancias de los estadios larvarios y de pupa en los que se encontraron las poblaciones de $\mathrm{H}$. exocellata en cada sitio de muestreo y fecha.

found at sites G2 (15.1 i.p.u.e. -individuals per unit of effort- in June'97), G3 (64.5 and 245.5 i.p.u.e. in June 1997 and October 1997, respectively), and G6 (145.5 i.p.u.e. in jun'97) (Fig. 1). The seasonal changes in abundance at each site were all significant (chi-squared goodness-of-fit test, $p=0 ; \mathrm{G} 2: \boldsymbol{\aleph}^{2}=138$; G3: $\boldsymbol{\aleph}^{2}=1006$; G6: $\boldsymbol{\aleph}^{2}=849 ; 3$ d.f. for all cases).
Figure 2 shows the percentages of abundance of the different $H$. exocellata larval instars and pupae during the whole study. It is apparent that the percentages are different at each site and date.

Regarding the spatial distribution, in those samplings where the abundances of $H$. exocellata were higher, the differences were also significant (chi-squared goodness-of-fit test, $p$ $=0$; June 1997: $\boldsymbol{\aleph}^{2}=187$; October 1997: $\boldsymbol{\aleph}^{2}=$ 954; 2 d.f. for two cases).

Stepwise multiple variable regression shows water current velocity as the only significant variable related to the abundances of $H$. exocellata (16.5\% of cumulative variation explained, $F=$ $4.55 ; p=0.0478)$.

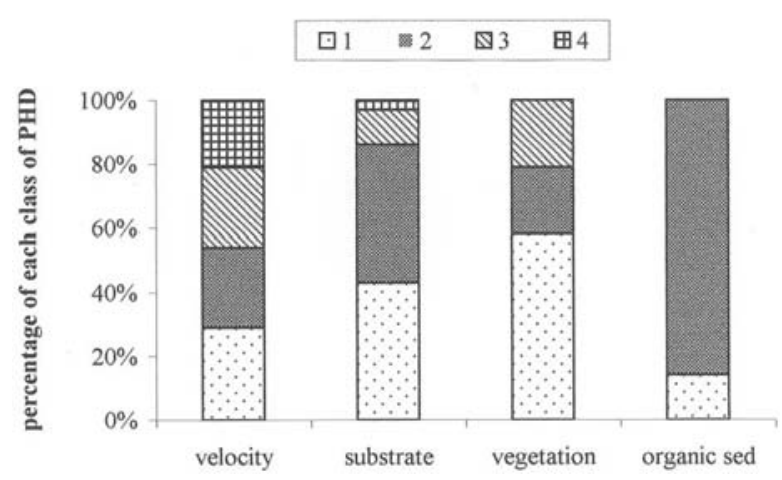

Figure 3. Percentages of frequencies found for each class of the four principal habitat descriptors (PHD) according to the criteria described in Table 1 available for $H$. exocellata. Porcentajes de frecuencias encontradas para cada clase de los cuatro descriptores principales del hábitat (PHD) según los criterios descritos en la Tabla 1 disponibles para $\mathrm{H}$. exocellata.

\section{Hydropsyche exocellata microhabitat selection}

From the criteria used to separate the microhabitats (Table 1), plus the stretch of the river where they were located, and the sampling date, we have distinguished a total of 28 microhabitats: 14 at site G2, 5 at site G3, and 9 at site G6 (Table 2). In these 28 microhabitats, the percentage of frequencies found for each class of the four principal habitat descriptors available for $H$. exocellata were as follows (Fig. 3): very similar for water current velocity $(29,25,25$, and $21 \%$ for classes $1,2,3$, and 4 respectively); those where sands or 
Table 2. Description of the 28 microhabitats sampled, according to the criteria used in Table 1 . V: water current velocity (cm/s), RA: relative abundance (individual per unit of effort) of $H$. exocellata, S: sampling site where the microhabitat is located, D: sampling date, IBMWP: values of this biological index found in the study area (Gallardo-Mayenco et al., 2004). Descripción de los 28 microhábitats muestreados, según los criterios usados en la Tabla 1. V: velocidad de la corriente de agua (cm/s), RA: abundancia relativa (individuos por unidad de esfuerzo) de $\mathrm{H}$. exocellata, S: sitio de muestreo donde se localiza el microhábitat, D: fecha del muestreo, IBMWP: valores de este índice biológico encontrado en el área de estudio (Gallardo-Mayenco et al., 2004).

\begin{tabular}{|c|c|c|c|}
\hline Microhabitat description & RA & S/Date & IBMWP \\
\hline $\mathrm{V}=0$; fine sand, Ranunculus sp. & 1 & G2 oct'96 & 84 \\
\hline$V=10$; fine sand, organic sediments & 0 & G2 oct'96 & 84 \\
\hline $\mathrm{V}=20$; fine sand + large stones covered with filamentous algae $+T$. domingensis & 0 & G2 oct'96 & 84 \\
\hline $\mathrm{V}=0 ;$ mixed sand, leaf litter & 0 & G2 feb’97 & 61 \\
\hline $\mathrm{V}=20 ;$ sand + stones & 1 & G2 feb'97 & 61 \\
\hline $\mathrm{V}=67 ;$ stones + coarse sand, litter of Juncus sp. & 0 & G2 feb’97 & 61 \\
\hline $\mathrm{V}=0 ;$ fine sand + little stones, $P$. communis & 0 & G2 jun’97 & 75 \\
\hline $\mathrm{V}=22 ;$ fine sand, leaf litter & 2 & G2 jun'97 & 75 \\
\hline $\mathrm{V}=33 ;$ mixed sand & 2 & G2 jun'97 & 75 \\
\hline $\mathrm{V}=33$; large stones + sand, Juncus sp. & 50 & G2 jun'97 & 75 \\
\hline $\mathrm{V}=0 ;$ mixed sand, filamentous algae & 0 & G2 oct'97 & 85 \\
\hline $\mathrm{V}=17 ;$ mixed sand & 0 & G2 oct'97 & 85 \\
\hline $\mathrm{V}=17 ;$ stone + sand, shoots of Juncus sp. & 0 & G2 oct'97 & 85 \\
\hline $\mathrm{V}=36 ;$ gravel, Juncus sp. & 2 & G2 oct'97 & 85 \\
\hline $\mathrm{V}=40 ;$ large stones covered with filamentous algae + gravel + pebble & 5 & G3 oct'96 & 31 \\
\hline $\mathrm{V}=50 ;$ slime, leaf litter & 0 & G3 feb’97 & 29 \\
\hline $\mathrm{V}=67$; large stone covered with filamentous algae & 64.5 & G3 jun'97 & 49 \\
\hline $\mathrm{V}=0 ;$ slime, grass, organic sediments & 0 & G3 oct'97 & 45 \\
\hline $\mathrm{V}=100 ;$ stones & 461 & G3 oct'97 & 45 \\
\hline $\mathrm{V}=0$; large stones, $L$. gibba, organic sediments & 0 & G6 oct'96 & 36 \\
\hline $\mathrm{V}=12 ;$ sand, leaf litter & 0 & G6 feb’97 & 46 \\
\hline $\mathrm{V}=50 ;$ sand, leaf litter & 0 & G6 feb'97 & 46 \\
\hline $\mathrm{V}=100 ;$ large stone covered with filamentous algae & 0 & G6 feb'97 & 46 \\
\hline $\mathrm{V}=50 ;$ mixed sand, shoots of Juncus sp. + filamentous algae & 103 & G6 jun’97 & 55 \\
\hline $\mathrm{V}=67 ;$ large stones, shoots of Juncus sp. & 188 & G6 jun'97 & 55 \\
\hline $\mathrm{V}=0$; stones covered with filamentous algae & 0 & G6 oct'97 & 59 \\
\hline $\mathrm{V}=0 ;$ slime, grass & 0.7 & G6 oct'97 & 59 \\
\hline$V=67 ;$ stones + coarse sand & 1.5 & G6 oct'97 & 59 \\
\hline
\end{tabular}

stones were predominant in the substrate (classes 1 and 2: $43 \%$ each); presence of vegetation (class 1) $57 \%$ frequency; and absence of organic sediments $(86 \%)$.

Next, the abundances of $H$. exocellata that were assigned at each class of the four principal habitat descriptors agree with the characteristics of the microhabitat where they were caught. Then, we found that the percentage of abundance of $\mathrm{H}$. exocellata was higher at fast water current velocity sites (class 4,81\%), on stones (class $2,87 \%$ ), indifferent to the presence (class 1 , $47 \%$ ) or absence (class 2, $53 \%$ ) of vegetation, and without organic sediments (100\%) (Fig. 4).
For each class of water current velocity and substrate, differences in the abundances were all significant (chi-squared goodness-of-fit test, $p=$ 0 all cases, water current velocity: $\aleph^{2}=1940 ; 3$ d.f., substrate: $\aleph^{2}=714 ; 3$ d.f.).

\section{DISCUSSION}

The absence of $H$. exocellata at sites G4 and G5 could be due to the organic pollution found in these areas (Gallardo-Mayenco et al., 2004), whereas its absence at site G1 could be related to the low water current velocity $(0.2 \mathrm{~m} / \mathrm{s}$ maxi- 


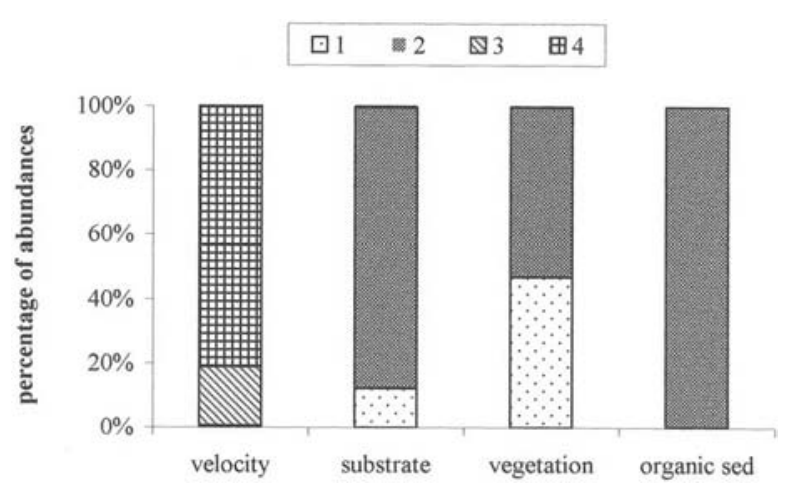

Figure 4. Percentages of abundance of $H$. exocellata found at each class of the four principal habitat descriptors according with the characteristics of the microhabitat where it was. Porcentajes de abundancia de H. exocellata encontrados en cada clase de los cuatro descriptores principales del hábitat de acuerdo con las características del microhábitat donde se encontró.

mum of velocity measured), since the IBMWP rank of this site was 104-29. On the other hand, the low density of $H$. exocellata at site G2 and its absence at sites G3 and G6 in February 1997, could be the result of streambed scouring caused by the flood (rainfall values were $385 \mathrm{~mm}$ in December 1996 and $137 \mathrm{~mm}$ in January 1997 against $95 \mathrm{~mm}$ and $76 \mathrm{~mm}$ of average respectively for the same months in the 1960-1990 period, see Gallardo-Mayenco et al. (2004)). Changes in the benthic macroinvertebrate densities after floods as a consequence of substrate disturbances in Mediterranean streams has been described by Gasith \& Resh (1999), and the negative effect of high flood on $H$. exocellata populations by Dolédec \& Tachet (1989). Scouring could be the reason for the impoverishment of macroinvertebrate communities in the study area in Feb'97 (Gallardo-Mayenco et al., 2004).

In this study, the distribution of $H$. exocellata was related to water current velocity, possibly due to availability of food resources and feeding (Muñoz \& Prat, 1994). Inputs of particulate organic matter, nitrogen, and phosphates favour Hydropsyche spp. populations (Basaguren, 1990; Basaguren \& Orive, 1993). Agricultural use of the Guadaira River watershed would supply this food resource (Delong \& Brusven, 1992).

H. exocellata showed preference towards microhabitats characterized by fast water current velocity ( $81 \%$ of its abundance) and stones $(87 \%)$, being indifferent to the presence or absence of vegetation. However, faster water current velocity by itself does not imply always the high abundances (Table 2).

On the other hand, Fairchild \& Holomuzki (2002) found that five Hydropsyche species preferred substrates formed by stones, which provided stability against high flows. In addition, Czachorowski (1989) found that Hydropsyquid larvae chose substrate with stones and gravels more than sandy ones. This could be in agreement with Hynes (1970) in the sense that habitats constituted by sands is "a place relatively unfilled". In spite of them, just like water current velocity, the prevalence of stones does not always mean higher abundances of $H$. exocellata (Table 2). Therefore, we can infer that neither water current velocity nor substrate can influence by themselves the abundances of $H$. exocellata. Some authors such as Sponseller et al., (2001) have related high densities of Hydropsychidae with filamentous algae. However, our results showed that the presence of filamentous algae was not determinant in the microhabitat selection of $H$. exocellata, although we did find high densities of this species in some microhabitats that included filamentous algae (Table 2).

\section{CONCLUSIONS}

The higher abundances of $H$. exocellata were found at the start of the drought (June) and at the end of the drought (October) periods. In reference to the IBMWP index, we found the highest densities of $H$. exocellata in a rank of 4575 (Table 2). According to the values proposed by Rieradevall et al. (1999) for Mediterranean streams, these coincided with the values of the IBMWP index characterizing at least moderately polluted waters. On the contrary, we did not find $H$. exocellata larvae at sites where pollution reached the highest levels (IBMWP ranks: 34 and 12-19 for G4 and G5 respectively). Because of this, and although $H$. exocellata has been recognized as a tolerant species to organic pollution and typical of downstream situations 
(Basaguren, 1990; Basaguren \& Orive, 1993; Usseglio-Polatera, 1993; De Soto et al., 1994), in the study area it avoids extremely polluted sites, and its absence in microhabitats with anoxic conditions could be related to this fact.

In general, our results agree with those from other authors (Graça et al., 1989; Basaguren \& Orive, 1993; Bonada et al., 2004b), in the way that $H$. exocellata is an ubiquitous species in terms of chemical water quality, though from the whole of our results, we can infer that to get a successful population size in the study area, it requires an environment basically consisting in a combination of a firm substrate (stones) plus a medium-fast water current velocity with a moderate content of organic matter.

\section{ACKNOWLEDGEMENTS}

The authors are grateful to Eric Shaw (The Gibraltar Ornithological \& Natural History Society) for his help with the English translation. The authors are also thankful to two anonymous referees that made useful comments and suggestions to an earlier version of the manuscript.

\section{REFERENCES}

ALBA-TERCEDOR, J., P. JÁIMEZ-CUÉLLAR, M. ÁLVAREZ，J. AVILÉS，N. BONADA，J. CASAS, A. MELLADO, M. ORTEGA, I. PARDO, N. PRAT, M. RIERADEVALL, S. ROBLES, C. SÁINZ-CANTERO, A. SÁNCHEZ-ORTEGA, M. L. SUÁREZ, M. TORO, M. R. VIDAL-ABARCA, S. VIVAS y C. ZAMORA-MUÑÓZ. 2002. Caracterización del estado ecológico de los ríos mediterráneos ibéricos mediante el índice IBMWP (antes BMWP'). Limnetica, 21: 175-185.

BARGOS, T., J. M. MESANZA, A. BASAGUREN \& E. ORIVE. 1990. Assessing river water quality by means of multifactorial methods using macroinvertebrates. A comparative study of main water courses of Biscay. Water Res., 24: 1-10.

BASAGUREN, A. 1990. Distribución de las especies pertenecientes a la familia Hydropsychidae (Trichoptera) en la cuenca del Lea (País Vasco). Scientia gerundensis, 16: 43-52.
BASAGUREN, A. y E. ORIVE. 1993. Composición y estructura de las comunidades de tricópteros en los ríos del País Vasco: Cuenca del Artibai. Limnetica, 9: 11-18.

BONADA, N., C. ZAMORA-MUÑOZ, M. RIERADEVALL \& N. PRAT. 2004a. Ecological profiles of caddisfly larvae in Mediterranean streams: implications for bioassessment methods. Environmental Pollution, 132: 509-521.

BONADA, N., C. ZAMORA-MUÑOZ, M. RIERADEVALL \& N. PRAT. 2004b. Trichoptera (Insecta) collected in Mediterranean river basins of the Iberian peninsula: taxonomic remarks and notes on ecology. Graellsia, 60: 41-69.

BONADA, N., C. ZAMORA-MUÑOZ, M. RIERADEVALL \& N. PRAT. 2005. Ecological and historical filters constraining spatial caddisfly distribution in Mediterranean rivers. Freshwat. Biol., 50: 781-797.

CZACHOROWSKI, S. 1989. Differentiation of the habitats of Hydropsychidae larvae (Insecta: Trichoptera) in the Pasteka river as a result of avoidance of trophic competition. Pol. Arch. Hydrobiol., 36: 123-132.

DE SOTO, J., M. FERNÁNDEZ-ALÁEZ, E. LUISCALABUIG \& C. FERNÁNDEZ-ALÁEZ. 1994. Spatial and temporal distribution of the caddisfly (Trichoptera) communities of the Sil basin (NW Spain). Verh. Internat. Verein. Limnol., 25: 17161722.

DELONG, M. D. \& M. A. BRUSVEN. 1992. Patterns of periphyton chlorophyll "a" in an agricultural nonpoint source impacted stream. Water Resources Bull., 28: 731-741.

DOLÉDEC, S., B. STATZNER \& M. BOURNARD. 1999. Species traits for future biomonitoring across ecoregions: patterns along a humanimpacted river. Freshwat. Biol., 42: 737-758.

DOLÉDEC, S. \& H. TACHET. 1989. Ecological observations and life histories of five net-spinning caddis flies (Trichoptera) of the lower Ardèche River. Aquatic Insects, 11: 89-99.

EDINGTON, J. M. \& A. G. HILDREW. 1981. A key to the Caseless caddis larvae of the British Isles. FBA, publ. no $43.91 \mathrm{pp}$.

ELLIOT, J. M. 1977. Some methods for the statistical analysis of samples of benthic invertebrates. Fresh. Biol. Asoc. Sc. Pub. No 25. 159 pp.

FAIRCHILD, M. P. \& J. R. HOLOMUZKI. 2002. Spatial variability and assemblage structure of 
stream hydropsychid caddisflies. J. N. Am. Benthol. Soc., 21: 576-588.

FERNÁNDEZ-ALÁEZ, C., J. DE SOTO, M. FERNÁNDEZ-ALÁEZ. \& F. GARCÍA-CRIADO. 2002. Spatial structure of the caddisfly (Insecta, Trichoptera) communities in a river basin in NW Spain affected by coal mining. Hydrobiologia, 487: 193-205.

GALLARDO-MAYENCO, A. 1994. Freshwater macroinvertebrate distribution in two basins with different salinity gradients (Guadalete and Guadaira river basins, south-western Spain). Internat. J. Salt Lake Res., 3: 75-91.

GALLARDO-MAYENCO, A., S. MACÍAS y J. TOJA. 2004. Efectos de la descarga en la calidad del agua a lo largo de un río mediterráneo: El río Guadaira (Sevilla). Limnetica, 23: 65-78.

GALLARDO-MAYENCO, A., J. PRENDA. \& J. TOJA. 1998. Spatio-temporal distribution and ecological preferences of coexisting Hydropsychid species (Trichoptera) in two Mediterranean river basins (S Spain). Internat. Rev. Hydrobiol., 83: 123-134.

GASITH, A. \& V. H. RESH. 1999. Streams in Mediterranean climate regions: abiotic influences and biotic responses to predictable seasonal events. Annu. Rev. Ecol. Syst., 30: 51-81.

GONZÁLEZ, M. A. 2003. http//www.fauna-iberica. mncn.csic.es/faunaib/arthropoda/insecta/ trichoptera/hydropsychidae.php

GONZÁlEZ, G., X. MILlET, N. PRAT. \& M. A. PUIG. 1985. Patterns of macroinvertebrate distribution in the Llobregat river basin (NE Spain). Verh. Internat. Verein. Limnol., 22: 2081-2086.

GRAÇA, M. A. S., D. M. FONSECA \& S. T. CASTRO. 1989. The distribution of macroinvertebrate communities in two Portuguese rivers. Freshwat. Biol., 22: 297-308.

HIGLER, L. W. G. \& H. H. TOLKAMP. 1983. Hydropsychidae as bio-indicators. Environ. Monitor. Assess., 3: 331-341.

HILDREW, A. G. \& J. M. EDINGTON. 1979. Factors influencing the coexistence of Hydropsychid caddis larvae (Trichoptera) in the same river system. J. Animal Ecol., 48: 557-576.
HYNES, H. B. N. 1970. The Ecology of Running Waters. Liverpool: Liverpool University Press. $555 \mathrm{pp}$.

McELHONE, M. J., R. W. DAVIES \& J. M. CULP. 1987. Factors influencing the abundance of Trichoptera in Hartley Creek, a brownwater stream in northeastern Alberta, Canada. Arch. Hydrobiol., 109: 279-285.

MUÑOZ, I. \& N. PRAT. 1994. Macroinvertebrate community in the lower Ebro river (NE Spain). Hydrobiologia, 286: 65-78.

OSBORNE, L. L. \& E. E. HERRICKS. 1987. Microhabitat characteristics of Hydropsyche (Trichoptera: Hydropsychidae) and the importance of body size. J. N. Am. Benthol. Soc., 6: 115-124.

PISCART, C., A. LECERF, P. USSEGLIO-POLATERA, J.-C. MORETEAU \& J.-N. BEISEL. 2005. Biodiversity patterns along a salinity gradient: the case of net-spinning caddisflies. Biodiversity and Conservation, 14: 2235-2249.

PRENDA, J. \& A. GALLARDO-MAYENCO. 1996. Self-purification, temporal variability and the macroinvertebrate community in small lowland Mediterranean streams receiving crude domestic sewage affluents. Arch. Hydrobiol., 136: 159-170.

RIERADEVALL, M., N. BONADA \& N. PRAT. 1999. Community structure and water quality in Mediterranean streams of a natural park (St. Llorenç del Munt, NE Spain). Limnetica, 17: 45-56.

RUÍZ-GARCÍA, A. 2000. Comunidades de Tricópteros (Trichoptera) de agua corriente en la provincia de Cádiz. Limnetica, 19: 83-90.

SOLER, G. y M. A. PUIG. 1999. Biología y producción de Efemerópteros y Tricópteros en el tramo medio del río Jalón (Alicante). Instituto de Cultura Juan Gil Albert. Diputación Provincial de Alicante. $201 \mathrm{pp}$.

SPONSELLER, R. A., E. F. BENFIELD \& H. M. VALETT. 2001. Relationship between land use, spatial scale and stream macroinvertebrate communities. Freshwat. Biol., 46: 1409-1424.

USSEGLIO-POLATERA, P. 1993. Graphical expresion of the ecological significance of a faunistic assemblage and its application to the study of the Rhône river Trichoptera at Lyons (France). Proc. $7^{\text {th }}$ Int. Symp. Trichoptera: $305-311$. 
